https://doi.org/10.19195/0137-1134.120.54

\author{
WOJCIECH JASIŃSKI \\ ORCID: 0000-0002-7427-1474 \\ Uniwersytet Wrocławski \\ Katedra Postępowania Karnego
}

\title{
RACJONALNA REGULACJA KARNOPROCESOWEJ DOPUSZCZALNOŚCI DOWODÓW UZYSKANYCH Z NARUSZENIEM PRAW JEDNOSTKI*
}

\begin{abstract}
Abstrakt: W artykule poddano analizie cztery wymogi, jakie muszą zostać spełnione przy tworzeniu racjonalnej regulacji karnoprocesowej dopuszczalności dowodów uzyskanych z naruszeniem praw jednostki. Pierwszy zakłada, że musi zostać dokonana zarówno rzetelna analiza dotychczasowego dorobku rodzimej teorii i funkcjonowania praktyki w omawianej sferze, jak i analiza komparatystyczna dotycząca dopuszczalności dowodów uzyskanych z naruszeniem praw jednostki. W dalszej kolejności uwzględnienia wymagają standardy konstytucyjny i prawnomiędzynarodowy, które kształtują nieprzekraczalne granice swobody, w jakich musi zmieścić się ustawodawca. Niezbędne jest również wyraźne zdefiniowanie celu, jakiemu mają służyć regulacje determinujące dopuszczalność dowodów uzyskanych z naruszeniem praw jednostki. Wyznaczy on bowiem ramy dla rozwiązań szczegółowych, gwarantując ich spójność. Ostatnią istotną kwestią jest kształt mechanizmu sankcjonowania dowodów uzyskanych z naruszeniem praw jednostki, który powinien zapewnić stosowną równowagę $\mathrm{w}$ dystrybucji władzy decydowania o dopuszczalności poszczególnych środków dowodowych między prawodawcą a organami stosującymi prawo oraz niezbędną elastyczność i gwarancje przeciwdziałające nadmiernej uznaniowości tych ostatnich.
\end{abstract}

Słowa kluczowe: nielegalnie uzyskane dowody, rzetelny proces, prawa jednostki, prawo dowodowe, dopuszczalność dowodów

Problematyka nielegalnie uzyskanych dowodów, w tym dowodów uzyskanych z naruszeniem praw jednostki, uznawana jest za jedno z najbardziej złożonych i kontrowersyjnych zagadnień prawa dowodowego ${ }^{1}$. Nie może zatem dziwić, że regulacje poświęcone tej problematyce są w poszczególnych państwach

* Artykuł powstał w ramach projektu naukowego finansowanego przez Narodowe Centrum Nauki numer 2017/27/B/HS5/00854: „Dopuszczalność dowodów w procesie karnym. Między poznaniem prawdy a rzetelnością i sprawnością postępowania”.

${ }^{1}$ Por. np. D. Giannoulopoulos, Improperly Obtained Evidence in Anglo-American and Continental Law, Oxford 2019, s. 1. Tak również w polskiej doktrynie: D. Szumiło-Kulczycka, Wykorzystanie w procesie karnym dowodów pochodzacych z czynności pozaprocesowych policji i innych działających 
bardzo zróżnicowane ${ }^{2}$. Co warte podkreślenia, odmienności te dotyczą w zasadzie wszystkich istotnych elementów konstrukcyjnych unormowania (unormowań), a także wykształconej praktyki stosowania prawa, dotyczących nielegalnie uzyskanych dowodów. W zależności więc od danego systemu prawnego różnie przedstawiają się zwłaszcza następujące kwestie: źródło normy prawnej (norm prawnych) regulującej możliwość wykorzystania w procesie karnym nielegalnie uzyskanych dowodów; zakres nielegalnie uzyskanych dowodów, które podlegają dyskwalifikacji; swoboda, która jest przyznawana organom stosującym prawo w podejmowaniu decyzji dotyczącej dopuszczenia dowodu; sposób reakcji na wadliwe uzyskanie dowodu oraz procedura orzekania o wykorzystaniu nielegalnie uzyskanych dowodów ${ }^{3}$. Biorąc pod uwagę wskazaną różnorodność, ustalenie, jak powinna wyglądać racjonalna regulacja karnoprocesowej dopuszczalności dowodów uzyskanych z naruszeniem praw jednostki w Polsce, wydaje się szczególnie problematyczne. Brakuje bowiem powtarzalnego albo wręcz uniwersalnego wzoru, który można byłoby uznać za optymalny teoretycznie, zweryfikowany w praktyce i dostosowany do lokalnych realiów.

$\mathrm{Na}$ wstępie rozstrzygnięcia wymaga to, jak rozumieć sformułowanie „racjonalna regulacja”. Nie wnikając w złożone aspekty teoretyczno-prawne, jakie wiążą się z tym sformułowaniem, będzie ono na potrzeby niniejszego opracowania rozumiane jako taka regulacja, która jest efektem przemyślanych działań, opartych na wiedzy dotyczącej normowania omawianej problematyki karnoprocesowej i uwarunkowań towarzyszących tworzeniu przepisów tej gałęzi prawa, podejmowanych z uwzględnieniem podstawowych zasad i wartości porządku prawnego, polegających na odpowiednim doborze środków dostępnych prawodawcy, zapewniających realizację legitymowanego celu, jaki stawia on przed tworzonymi regulacjami.

Rozwijając tę kwestię w kontekście normowania karnoprocesowej dopuszczalności dowodów uzyskanych z naruszeniem praw jednostki, należy stwierdzić, że warunkiem stworzenia racjonalnej regulacji jest, po pierwsze, rzetelna analiza zarówno dotychczasowego dorobku rodzimej teorii, funkcjonowania praktyki w omawianej sferze, jak i refleksja komparatystyczna nad regułami dotyczącymi dowodów uzyskanych z naruszeniem praw jednostki. Po drugie, należy uwzględnić pewne stałe determinujące zakres potencjalnych wyborów w zakresie regulacji dopuszczalności dowodów uzyskanych z naruszeniem praw jednostki. Chodzi

stużb — raporty krajowe, [w:] Pozaprocesowe pozyskiwanie dowodów i ich wykorzystanie w procesie karnym, red. P. Hofmański, D. Szumiło-Kulczycka, P. Czarnecki, Warszawa 2015, s. 57.

2 Por. m.in. Exclusionary Rules in Comparative Law, red. S.C. Thaman, Dordrecht 2013, passim; S.C. Thaman, ,Fruits of the poisonous tree” in comparative law, „Southwestern Journal of International Law" 2010, nr 16, s. 333-384; D. Giannoulopoulos, op. cit.; Do Exclusionary Rules Ensure a Fair Trial? A Comparative Perspective on Evidentiary Rules, red. S. Gless, T. Richter, Cham 2019; K. Hsiek, The Exclusionary Rule of Evidence. Comparative Analysis and Proposals for Reform, London-New York 2016. W polskiej doktrynie: W. Jasiński, Nielegalnie uzyskane dowody w procesie karnym. W poszukiwaniu optymalnego rozwiąania, Warszawa 2019, s. 213-308.

3 Tematykę tę omawiam szerzej w: W. Jasiński, op. cit., s. 213-308. 
przede wszystkim o ograniczenia natury konstytucyjnej oraz prawnomiędzynarodowej, które muszą zostać uwzględnione przy kreowaniu norm ustawowych. W tym kontekście warto podkreślić, że wskazane ograniczenia nie wynikają wyłącznie z wyrażonych expressis verbis reguł prawa dowodowego odnoszących się do nielegalnie uzyskanych dowodów, ale mogą podlegać rekonstrukcji na podstawie bardziej ogólnych regulacji (na przykład odwołujących się do rzetelności proceduralnej) oraz, co bardzo ważne, z uwzględnieniem konstytucyjnego systemu wartości. Po trzecie, niezbędne jest zdefiniowanie celu, jakiemu mają służyć unormowania dotyczące dopuszczalności dowodów uzyskanych z pogwałceniem praw jednostki. Po czwarte, ustalenia wymaga optymalny charakter i zakres regulacji ustawowej, determinujący zwłaszcza sposób dystrybucji władzy decydowania o dopuszczalności poszczególnych dowodów pomiędzy prawodawcę a organy stosujące prawo. Wskazane kwestie zostaną kolejno poddane analizie.

Najpierw należy pokusić się o syntetyczne podsumowanie dorobku krajowego i obcego w zakresie regulacji karnoprocesowej dopuszczalności dowodów uzyskanych z naruszeniem praw jednostki. Jeżeli przyjrzeć się unormowaniom krajowym i dorobkowi doktryny, trzeba stwierdzić, że zebrane doświadczenia są dość ograniczone ${ }^{4}$. Nie może to zaskakiwać. W okresie PRL bez wątpienia nie było podatnego gruntu do szerszego zainteresowania się omawianą kwestią, choćby z tego powodu, że wiązała się ona z marginalizowaną ówcześnie koncepcją praw jednostki. Także lata dziewięćdziesiąte i okres transformacji ustrojowej, ze względu na konieczność licznych i bardziej palących reform, nie przyniósł zasadniczej zmiany w analizowanej sferze. W momencie zaś, gdy problematyka dowodów uzyskanych z naruszeniem prawa (w tym uprawnień jednostki) nabrała znaczenia i stała się przedmiotem reform legislacyjnych (nowelizacje k.p.k. w latach 2013-2016) oraz bardziej ożywionego zainteresowania doktryny, rzetelną dyskusję i weryfikację praktyczną przyjętych rozwiązań uniemożliwiło wypierające racjonalny dyskurs upolitycznienie problematyki zmian procesu karnego. W konsekwencji w sferze dopuszczalności dowodów uzyskanych z naruszeniem prawa doszło do nadania centralnemu dla omawianej problematyki art. 168a k.p.k. treści, która zarówno w kontekście założeń aksjologicznych polskiego procesu karnego, jak i nawet samego jego ujęcia językowego wygenerowała więcej wątpliwości, niż rozstrzygnęła dotychczas istniejących w tej materii dylematów ${ }^{5}$. Warto też zauważyć, że rodzimy dorobek doktrynalny w kwestii dopuszczalności dowodów uzyskanych z naruszeniem prawa trudno uznać za obszerny i wyczerpujący. W zasadzie dopiero pierwsze dwie dekady XXI wieku przyniosły znaczący wzrost zainteresowania tą problematyką ${ }^{6}$. Poza obiektywnymi czynnikami spo-

${ }^{4}$ Szeroko omawiam te kwestie w: ibidem, s. 309-364, 395-492.

5 W kwestii analizy przepisu art. 168a k.p.k. por. ibidem, s. 502 n. oraz cytowana tam literatura i orzecznictwo.

${ }^{6}$ Szerzej w tej kwestii zob. ibidem, s. 309-364, 395-492. Nie oznacza to oczywiście, że wcześniej zagadnienie to nie było w literaturze podejmowane. W tym kontekście można wskazać 
łeczno-politycznymi, które oddziaływały na naukę prawa karnego procesowego, zaważył na tym, jak się wydaje, również sposób konceptualizacji podejścia do wadliwie uzyskanych dowodów. W polskiej tradycji karnoprocesowej problematyka ta jest bowiem dyskutowana w ramach szerszej koncepcji zakazów dowodowych. Tymczasem te ostatnie dotyczą nie tylko dowodów uzyskanych niezgodnie $\mathrm{z}$ prawem, ale też tych uzyskanych legalnie, które $\mathrm{z}$ innych powodów nie mogą zostać wykorzystane w procesie karnym (na przykład art. 182 § 1 k.p.k.). Zakazy dowodowe odnoszą się ponadto nie tylko do możliwości wykorzystania dowodu (co jest kluczowe w wypadku nielegalnie uzyskanych dowodów), lecz także do gromadzenia, przeprowadzania czy substytuowania dowodu. Biorąc to pod uwagę, można powiedzieć, że kwestia nielegalnie uzyskanych dowodów nieco niknie w ramach szerokiej i wieloaspektowej problematyki zakazów dowodowych i nie jest prawdopodobnie tak eksponowana, jak by była, gdyby nadano jej odrębny status w badaniach ${ }^{7}$. Reasumując, należy wskazać, że zarówno na gruncie teoretycznym, jak i w warstwie legislacyjnej oraz orzeczniczej trudno mówić o ukształtowanym i ugruntowanym dorobku, które stanowiłby mocny punkt odniesienia determinujący prace nad regulacją karnoprocesowej dopuszczalności dowodów uzyskanych z naruszeniem praw jednostki.

Ustalenie takie sprawia, że bardzo ważnego znaczenia nabiera analiza prawnoporównawcza, w szczególności odnosząca się do porządków prawnych, w których refleksja nad dopuszczalnością dowodów nielegalnych ma bardziej ugruntowaną tradycję. Oczywiście należy pamiętać, że dorobek innych państw nie może zostać mechanicznie i automatycznie przeniesiony na polski grunt. Jak bowiem wskazywałem w innym miejscu, podejście do problematyki dowodów nielegalnych jest $\mathrm{w}$ dużej mierze efektem historycznego rozwoju poszczególnych systemów prawnych ${ }^{8}$. Niemniej jednak warto korzystać z cudzych doświadczeń, gdyż są one cenną wskazówką, której uwzględnienie może pozwolić na uniknięcie błędnych założeń czy wyboru nieefektywnych metod realizacji zamierzonych celów. Dokonując zatem swoistego podsumowania doświadczeń państw z kręgu prawa kontynentalnego oraz common law, należy sformułować następujące konkluzje.

Po pierwsze - co wydaje się truizmem, ale biorąc pod uwagę aktualnie obowiązującą treść art. 168a k.p.k. wymaga podkreślenia — fakt naruszenia prawa, czy ściślej — praw i wolności jednostki, w toku pozyskiwania dowodów wymaga

przede wszystkim: R. Kmiecik, Dowód ścisty w procesie karnym, Lublin 1983; Z. Sobolewski, Samooskarżenie $w$ świetle prawa karnego (nemo se ipsum accusare tenetur), Warszawa 1982; idem, Illegal evidence and the Polish criminal procedure, „Annales Universitatis Mariae Curie-Skłodowska" 1988, nr 1, s. 313-328; idem, Wartość nielegalnie uzyskanego dowodu w postępowaniu karnym, „Annales Universitatis Mariae Curie-Skłodowska” 1976, nr 1, s. 45-58; Z. Kwiatkowski, Zakazy dowodowe w procesie karnym, Kraków 2005.

7 Warto zauważyć, że w krajach anglosaskich, gdzie dogmatyka prawa karnego procesowego i prawa dowodowego nie posługuje się koncepcją zakazu dowodowego, zagadnienie to jest w opracowaniach podręcznikowych wyodrębnione jako osobny problem.

8 W. Jasiński, op. cit., s. 301. 
uwzględnienia w toku oceny ich dopuszczalności. Niekoniecznie oznacza to automatyczny skutek w postaci dyskwalifikacji wadliwego dowodu, ale niewątpliwie nie jest to okoliczność, którą można by zbagatelizować. Warto zresztą zauważyć, że niektóre kraje świata wprost konstytucjonalizują reguły odnoszące się do dyskwalifikacji nielegalnie uzyskanych dowodów (por. Portugalia, Grecja, Chorwacja, Turcja, RPA, Kanada, Federacja Rosyjska, Białoruś, Ukraina, Azerbejdżan, Kazachstan, Gruzja). Świadczy to wyraźnie o randze omawianego problemu.

Po drugie, doświadczenia innych państw wskazują, że nadmierna złożoność systemu procesowej weryfikacji dopuszczalności dowodów uzyskanych z naruszeniem praw jednostki nie służy jednolitości stosowania prawa. Dotyczy to zarówno mnożenia instytucji prawnych, które miałyby służyć eliminowaniu takich dowodów (na przykład nieważność, niewykorzystywalność dowodu), jak i nadmiernej fragmentaryzacji i kazuistyki w regulowaniu omawianej problematyki. To ostatnie powoduje również, że widoczny staje się aktywizm sądów, które opierając się na regulacjach ponadustawowych, próbują wywieść niedopuszczalność wykorzystania dowodu także w takich sytuacjach, których regulacje karnoprocesowe wprost nie obejmują ${ }^{9}$. Potwierdzają to zresztą rodzime doświadczenia związane $\mathrm{z}$ wykreowanymi orzeczniczo regułami wykorzystania w procesie karnym materiałów uzyskanych w drodze czynności operacyjno-rozpoznawczych ${ }^{10}$. Oczywiście naiwnością byłoby sądzić, że ustawodawca jest w stanie stworzyć unormowania, które nie musiałyby podlegać interpretacji sądów. Tym niemniej charakter przyjmowanych regulacji prawnych niewątpliwie zawęża albo poszerza to pole. Jak wskazywałem w innym miejscu, w kontekście prawnoporównawczym

w zasadzie rzadkością jest [...] sytuacja, w której status procesowy nielegalnie uzyskanych dowodów jest rozstrzygany jednoznacznie przez jedno unormowanie albo jednolite orzecznictwo sądowe. Dominuje raczej sposób regulacji będący konglomeratem unormowań dotyczących tej materii albo mieszanką ustawowo oraz orzeczniczo wykreowanych reguł dyskwalifikacji dowodów nielegalnych ${ }^{11}$.

Nie oznacza to jednak, że rodzimy porządek normatywny jest skazany na nieredukowalną złożoność i nieprzejrzystość. Wskazane zjawiska są w dużej mierze efektem nielinearnego rozwoju krajowych regulacji prawnych. W wypadku Polski, która — jak zauważono na wstępie — nie ma w omawianym względzie jakichś ugruntowanych tradycji, warto więc wyciągnąć wnioski z obcych doświadczeń i dążyć do redukcji nadmiernej złożoności projektowanych regulacji prawnych.

Po trzecie, analiza sposobu funkcjonowania reguł odnoszących się do dopuszczalności dowodów uzyskanych z naruszeniem praw jednostki wskazuje, że

${ }^{9}$ Dobrym przykładem jest niemiecki porządek prawny. Szerzej zob. ibidem, s. 258-265; D. Gruszecka, [w:] System Prawa Karnego Procesowego, t. 8. Dowody, cz. 1, red. J. Skorupka, Warszawa 2019, s. 1083-1088.

${ }^{10}$ Szerzej o tym orzecznictwie zob. W. Jasiński, op. cit., s. 454-469.

11 Ibidem, s. 302. 
istotne znaczenie ma przyjmowana racjonalizacja procesowego sankcjonowania ${ }^{12}$ takich dowodów ${ }^{13}$. Dobrą ilustracją są tu Stany Zjednoczone, gdzie można zaobserwować historyczne przeobrażenia $\mathrm{w}$ tym zakresie (zmiana $\mathrm{z}$ uzasadnienia w postaci ochrony praw jednostki na tak zwane detterence principle), wynikające ze zmiany podejścia amerykańskiego Sądu Najwyższego do interpretacji charakteru i właśnie celu wywodzonych z praw jednostki zagwarantowanych w poprawkach do Konstytucji USA reguł eliminacji dowodu ${ }^{14}$. Oczywiście nie w każdym porządku normatywnym ustawodawca albo organ stosujący prawo (w precedensach) jednoznacznie przesądza o tym, z jakich powodów należałoby eliminować nielegalnie uzyskane dowody. Sprawia to więc, że w praktyce problematyka ta jest przez sądy albo pomijana, albo rozbieżnie rozumiana ${ }^{15}$. W konsekwencji racjonalnym rozwiązaniem jest takie ujęcie projektowanych regulacji prawnych, które wyraźnie określi racjonalizację dla procesowego sankcjonowania nielegalnie uzyskanych dowodów. Należy jednak podkreślić, że sam fakt, iż dany dowód został uzyskany z naruszeniem praw jednostki, nie musi oznaczać, że powodem przemawiającym za stosowaniem sankcji procesowej jest właśnie ta okoliczność. Warto zresztą odnotować, że odwołanie do uzasadnienia w postaci konieczności reakcji na naruszenie praw jednostki może przybrać przynajmniej kilka różnych form ${ }^{16}$. Należy również dostrzec, że w literaturze podnosi się, iż w praktyce stosowania prawa nawet wyraźne odwołanie się do określonej racjonalizacji sankcjonowania nielegalnie uzyskanych dowodów nie musi determinować decyzji zapadających w sprawach indywidualnych ${ }^{17}$, gdyż często są one wypadkową uwzględniania ad hoc różnych pozostających z sobą w konflikcie racji. Niemniej jednak nie dyskwalifikuje to celowości określenia choćby ogólnych priorytetów aksjologicznych, które będą determinować wybory sędziów. Zabieg taki bowiem przynajmniej w pewnym zakresie będzie sprzyjał jednolitości stosowania prawa.

Po czwarte, nie ulega wątpliwości, że sankcjonowanie uzyskania dowodu z naruszeniem praw jednostki nie może być prostym i automatycznym mechanizmem. Pluralizm racji, które wymagają wzięcia pod uwagę w tym procesie (w szczególności: sprawiedliwość materialna, skuteczność ścigania sprawców przestępstw,

12 Termin „sankcjonowanie” rozumiany jest jako stosowanie określonej sankcji (procesowej) będącej reakcją na naruszenia prawa $\mathrm{w}$ toku gromadzenia dowodów, a nie uprawomocnianie czy zatwierdzanie określonego stanu rzeczy.

13 Problematykę tą omawiam w: ibidem, s. 85-147.

14 Szerzej w tej kwestii zob. K. Kremens, Dostęp do obrońcy (adwokata) w orzecznictwie Sądu Najwyższego USA (Doktryna Mirandy), „Europejski Przegląd Sądowy” 2018, nr 1, s. 31-37; W. Jasiński, op. cit., s. 85-147.

15 Szerzej zob. W. Jasiński, op. cit., s. 85-147.

${ }^{16}$ Szerzej zob. P. Roberts, Excluding evidence as protecting constitutional or human rights?, [w:] Principles and Values in Criminal Law and Criminal Justice. Essays in Honour of Andrew Ashworth, red. L. Zedner, J.V. Roberts, Oxford-New York 2012, s. 163-193.

17 J.I. Turner, T. Weigend, The purposes and functions of exclusionary rules: A Comparative overview [w:] Do Exclusionary Rules..., s. 280. 
bezpieczeństwo państwa i jednostek, lecz także poszanowanie praw człowieka, moralna legitymacja wymiaru sprawiedliwości, promowanie legalności działania organów ścigania), sprawia, że nie sposób zadekretować na przykład, iż wszystkie naruszenia praw jednostki muszą skutkować niedopuszczalnością dowodu. W ustalaniu właściwej reakcji na pogwałcenie praw człowieka w postępowaniu dowodowym uwzględnione powinny niewątpliwie zostać: rodzaj i charakter naruszonego prawa, rola jego beneficjenta w procesie karnym, rozmiar wyrządzonej szkody, wpływ naruszenia danego prawa na pozycję jednostki w procesie karnym, okoliczności i charakter naruszenia prawa oraz bezpośredniość albo pośredniość wpływu naruszenia prawa na pozyskanie dowodu ${ }^{18}$.

Po piąte, analiza porządków prawnych innych państw wskazuje, że nie mamy do czynienia z jednym schematem dotyczącym tego, kto i na jakim poziomie przesądza o konieczności zastosowania sankcji procesowej w wypadku wadliwego pozyskania dowodu. $Z$ jednej strony można wskazać na rozwiązania normatywne, w których kwestia ta rozstrzygana jest przez ustawodawcę. Z drugiej jednak widocznym trendem jest zawarcie w przepisach prawa pisanego uprawnienia dla organów procesowych (najczęściej sądu) do rozstrzygnięcia omawianego zagadnienia. Nie sposób nie wspomnieć też o tym, że decyzje zapadające w odniesieniu do omawianej materii podejmowane są przez sądy również w sytuacjach, gdy nie ma wprost sformułowanej normy kompetencyjnej dotyczącej sankcjonowania określonej kategorii dowodów naruszających prawa jednostki. W takich okolicznościach decydują one, opierając się na unormowaniach konstytucyjnych lub prawnomiędzynarodowych nawiązujących do wymogu rzetelności proceduralnej ${ }^{19}$. Zasadniczo można zatem zaobserwować mniejszy lub większy, ale jednak wyraźnie widoczny zakres swobody pozostawiony organom procesowym w rozstrzyganiu o procesowym sankcjonowaniu dowodów uzyskanych z naruszeniem praw jednostki ${ }^{20}$.

Po szóste, wskazana sfera dyskrecjonalności wiąże się z widocznym trendem do poszukiwania alternatyw procesowego sankcjonowania pozyskania dowodu z naru-

18 To, jak istotną rolę odgrywają te czynniki, widoczne jest choćby w orzecznictwie ETPCz dotyczącym nielegalnie uzyskanych dowodów i ich dopuszczalności w procesie karnym.

19 Dobrym przykładem w tym zakresie są Niemcy. Por. np. T. Weigend, The potential to secure a fair trial through evidence exclusion: A German perspective, [w:] Do Exclusionary Rules..., s. 61-91.

${ }^{20}$ Por. rozważania komparatystyczne w: W. Jasiński, op. cit., s. 213-308. Por. też np. D. Giannoulopoulos, op. cit., s. 228-248. Niekiedy ów zakres swobody jest wyinterpretowany z na pierwszy rzut oka jednoznacznych przepisów ustawowych. Przykładem jest orzecznictwo hiszpańskiego Trybunału Konstytucyjnego dotyczące art. 11 ust. 1 ustawy organicznej o władzy sądowniczej, stanowiącego, że nie wywołują skutków dowody, które zostały uzyskane bezpośrednio lub pośrednio z naruszeniem praw i wolności fundamentalnych. Organ ten przez wzgląd na interes społeczny ograniczył zakres zastosowania tego przepisu w wypadku tak zwanych owoców zatrutego drzewa. Por. L. Bachmaier, [w:] L. Bachmaier, A. del Moral Garcia, Criminal Law in Spain, Alphen aan den Rijn 2012, s. 252. 
szeniem praw jednostki. Biorąc pod uwagę znaczenie pozostających w konflikcie w wypadku decydowania o dopuszczalności dowodu dóbr, takie podejście nie może zaskakiwać. Nieracjonalne byłoby bowiem przyjęcie skrajnego stanowiska, zakładającego, że każdego rodzaju uchybienie musi automatycznie prowadzić do daleko idącego skutku, jakim jest eliminacja wadliwie uzyskanego dowodu, i dalszych tego konsekwencji z potencjalnym uniewinnieniem włącznie. Jeżeli jednak ustawodawca albo organy stosujące uznają, że powinno dojść do wyciągnięcia procesowych konsekwencji wadliwości dowodu, to najczęściej stosowaną sankcją jest właśnie niemożność wykorzystania danego dowodu jako podstawy faktycznej wydanego w sprawie orzeczenia. Można co prawda wskazać także inne stosowane sankcje (łagodzenie wymierzanych sankcji karnych w wypadku drobniejszych naruszeń prawa dowodowego $^{21}$, umorzenie postępowania ${ }^{22}$ ), ale są to rozwiązania raczej wyjątkowe.

Wyciągnięciu wniosków z doświadczeń innych państw w zakresie procesowego sankcjonowania dowodów uzyskanych z naruszeniem praw jednostki musi towarzyszyć uwzględnienie konstytucyjnych oraz prawnomiędzynarodowych unormowań dotyczących tej materii. Wyznaczają one bowiem, w związku z określoną w ustawie zasadniczej hierarchią źródeł prawa, nieprzekraczalne ramy, w jakich musi zmieścić się ustawodawca. W ramach tych musi oczywiście mieścić się również organ stosujący prawo. Dobrym przejawem realizacji takiego obowiązku w kontekście dopuszczalności nielegalnie uzyskanych dowodów jest postanowienie SN z dnia 26 czerwca 2019 roku $^{23}$, w którym wskazano, że

art. 168a k.p.k. nie może stanowić podstawy prawnej przeprowadzenia dowodu uzyskanego z naruszeniem przepisów postępowania lub za pomocą czynu zabronionego, jeżeli przeprowadzenie takiego dowodu czyniłoby proces nierzetelnym w rozumieniu art. 6 ust. 1 Konwencji o Ochronie Praw Człowieka i Podstawowych Wolności.

Należy jednak mieć świadomość, że rekonstrukcja wspomnianych ram nie jest zadaniem łatwym. W wypadku dopuszczalności nielegalnie uzyskanych dowodów zasadniczym problemem jest bardzo ogólny charakter unormowań konstytucyjnych oraz konwencyjnych. Nie odnoszą się one bowiem do wskazanej kwestii wprost ${ }^{24}$. Istotne w omawianym zakresie standardy można wywodzić jedynie pośrednio z regulacji wprowadzających wymóg rzetelności proceduralnej (przede wszystkim art. 45 ust. 1 Konstytucji RP oraz art. 6 ust. 1 Europejskiej konwencji

21 Por. art. 359a kodeksu postępowania karnego - https://wetten.overheid.nl/BWBR0001903/2020-01-01/\#BoekTweede_TiteldeelVI_AfdelingVierde_Artikel359a (dostęp: 14.05.2020).

22 Stay of proceedings w prawie angielskim. Por. W. Jasiński, op. cit., s. 221.

23 Sygn. IV KK 328/18, OSNK 2019, z. 8, poz. 46.

24 Wyjątkiem jest jedynie wiążący Polskę art. 15 Konwencji w sprawie zakazu stosowania tortur oraz innego okrutnego, nieludzkiego lub poniżającego traktowania albo karania, który stanowi, że każde państwo-strona zapewnia, aby jakiekolwiek oświadczenie, które — jak ustalono — zostało złożone w wyniku zastosowania tortur, nie zostało wykorzystane w charakterze dowodu w postępowaniu, z wyjątkiem wypadku, gdy jest ono wykorzystywane przeciwko osobie oskarżonej o stosowanie tortur jako dowód na to, że oświadczenie zostało złożone. 
o ochronie praw człowieka i podstawowych wolności). W takich okolicznościach kluczowego znaczenia nabiera orzecznictwo sądów i trybunałów dokonujące interpretacji wspomnianego standardu. Szeroko zagadnienie to omówiłem w innym miejscu ${ }^{25}$.

Próbując krótko zdefiniować ramy, w jakich powinien operować ustawodawca, należy wskazać, że w bardzo ograniczonym zakresie mają one sztywny charakter. Tak jest w odniesieniu do dowodów osobowych, które zostały uzyskane w wyniku tortur albo innego nieludzkiego lub poniżającego traktowania, oraz dowodów rzeczowych uzyskanych bezpośrednio w wyniku stosowania tortur, które są bezwzględnie niedopuszczalne ${ }^{26}$. Podobnie rzecz ma się z dowodami uzyskanymi w wyniku nielegalnej prowokacji policyjnej ${ }^{27}$. W dużo szerszym zakresie standardy o charakterze ponadustawowym wskazują jedynie na określony poziom staranności, jakiego musi dochować w toku dopuszczania dowodów przez sąd karny. Wiąże się on najczęściej z doprecyzowaniem przesłanek, jakie powinny zostać uwzględnione w procesie decyzyjnym, oraz wskazaniem na konieczność rzetelnego uzasadnienia wydanego rozstrzygnięcia. Do takiej sytuacji dochodzi w wypadku dowodów rzeczowych uzyskanych w wyniku innych niż tortury form nieludzkiego lub poniżającego traktowania oraz dowodów uzyskanych z naruszeniem prawa do prywatności, prawa do nieobciążania się, a także prawa dostępu do adwokata. We wskazanych wypadkach, w których decydujące znaczenie dla kształtowania wiążącego Polskę standardu międzynarodowego ma orzecznictwo Europejskiego Trybunału Praw Człowieka interpretującego art. 6 ust. 1 EKPCz, brakuje niestety spójnego i jednolitego dla wszystkich wymienionych kategorii dowodów schematu postępowania, jaki miałby stosować sąd krajowy. Trybunał strasburski wymienia różne czynniki, które muszą zostać uwzględnione, nie wskazuje jednak żadnych kryteriów preferencji i zaistniałe naruszenie nakazuje oceniać holistycznie na tle całokształtu postępowania (overall fairness of proceedings) ${ }^{28}$. Niewątpliwie komplikuje to aplikowanie wskazanego standardu na poziomie krajowym. Nie zmienia to jednak faktu, że wskazówki sformułowane przez Europejski Trybunał Praw Człowieka należy traktować jako wiążące ${ }^{29}$.

25 Por. W. Jasiński, op. cit., s. 365-394.

26 Szerzej zob. W. Jasiński, Karnoprocesowa dopuszczalność dowodów uzyskanych w wyniku tortur (standardy strasburskie), „Państwo i Prawo” 2011, nr 5, s. 44-56.

${ }^{27}$ M. Wąsek-Wiaderek, Model zakazów dowodowych z perspektywy Konwencji oraz orzecznictwa ETPCz, [w:] Nowe spojrzenie na model zakazów dowodowych w procesie karnym, red. J. Skorupka, A. Drozd, Warszawa 2016, s. 23.

28 Bardzo dobrą ilustracją takiego podejścia jest wyrok ETPCz z 13 września 2016 roku, skarga nr 50541/08, 50571/08, 50573/08 i 40351/09, Ibrahim i inni przeciwko Zjednoczonemu Królestwu.

${ }^{29}$ Ze względu na ramy objętościowe niniejszej publikacji pomijam szersze rozważania na temat wiążącego charakteru standardów kreowanych przez ETPCz. Przyjmuję jednak, że takowy one mają. Szerzej zob. W. Jasiński, Nielegalnie..., s. 366-373. Por. trafne uwagi w tej kwestii w: A. Bodnar, Wykonywanie orzeczeń Europejskiego Trybunatu Praw Człowieka w Polsce. Wymiar instytucjonalny, Warszawa 2018, s. 109 n. 
W przeciwieństwie do rozwijającego się standardu strasburskiego dość trudno natomiast wskazać kształt konstytucyjnego standardu dopuszczalności dowodów uzyskanych z naruszeniem praw jednostki. Analiza orzecznictwa Trybunału Konstytucyjnego wskazuje, że nie ma wypowiedzi wprost odnoszących się do tej kwestii. Jest ona natomiast poruszana w doktrynie procesu karnego oraz orzecznictwie sądowym. Należy jednak zwrócić uwagę na istotne rozbieżności tam się pojawiające, a także na to, iż zazwyczaj jako punkt odniesienia do dość ogólnych rozważań służą równie ogólne regulacje konstytucyjne (art. 2, 7, 45, 47 czy 50 Konstytucji RP). W zasadzie jedynym wyjątkiem jest powoływanie się na art. 51 ust. 4 Konstytucji RP jako podstawę eliminacji dowodu uzyskanego sprzecznie z ustawą. Stanowisko to jest jednak przynajmniej wysoce dyskusyjne ${ }^{30}$. Reasumując, należy więc stwierdzić, że polski standard konstytucyjny w kwestii dopuszczalności dowodów uzyskanych z naruszeniem praw jednostki w najlepszym wypadku dopiero się kształtuje. Do jego rozwoju niewątpliwie przyczyniłoby się najlepiej pogłębione merytorycznie i cieszące się autorytetem orzecznictwo Trybunału Konstytucyjnego. Biorąc jednak pod uwagę to, w jakiej kondycji znajduje się obecnie ten organ ${ }^{31}$, trudno oczekiwać, że w najbliższym czasie to nastąpi. De lege lata zaś przy braku wyraźnych wskazówek ustrojodawcy oraz orzecznictwa sądu konstytucyjnego nie sposób przyjąć, że standard konstytucyjny wykracza poza ten wyznaczony przez akty prawa międzynarodowego, które Polska zobowiązała się przestrzegać.

Wziąwszy pod uwagę wskazane doświadczenia krajowe i zagraniczne, a także wyznaczane przez akty ponadustawowe ramy swobody legislacyjnej, ustawodawca w pierwszej kolejności powinien ustalić, jaki cel (cele) miałby zostać zrealizowany dzięki karnoprocesowemu sankcjonowaniu dowodów uzyskanych z naruszeniem praw jednostki. Odpowiedź na to pytanie jest bardzo istotna, gdyż pozwala, przy konsekwentnym dostosowaniu do niej przyjętych regulacji prawnych, na zapewnienie spójności przyjmowanych unormowań. Choć, jak zostało to już wskazane, nie można w precyzyjnym określeniu celu uchwalanych przepisów upatrywać cudownego remedium na rozbieżności interpretacyjne pojawiające się w praktyce, to jednak bez wątpienia jest to czynnik, który pozwoli je zredukować. Nie można przy tym nie dostrzec, że określenie takiego celu jest problematyczne. Odwołanie się do konieczności zagwarantowania rzetelnego procesu karnego czy moralnej integralności sądownictwa nie musi być jednolicie rozumiane ${ }^{32}$. Nie

30 Szerzej zob. W. Jasiński, Nielegalnie..., s. 391-394.

31 Trafnie wskazują P. Tuleja i P. Radziewicz, że w wypadku Trybunału Konstytucyjnego mamy do czynienia z najgłębszym kryzysem konstytucyjnym III RP. Jak podnoszą, „związany był on początkowo z wyborem sędziów Trybunału Konstytucyjnego. Stosunkowo szybko przekształcił się jednak w kryzys dotyczący ustrojowych podstaw działania Trybunału i braku możliwości sprawowania przez Trybunał jego podstawowych konstytucyjnych zadań" — eidem, [w:] Konstytucyjny spór o granice zmian organizacji i zasad działania Trybunału Konstytucyjnego: czerwiec 2015-marzec 2016, red. P. Tuleja, P. Radziewicz, Warszawa 2017, s. 21.

32 Por. W. Jasiński, Nielegalnie..., s. 115-135. 
sposób także oczekiwać zgodności poglądów odnoszących się do wskazanej kwestii $^{33}$. Nie można jednak traktować tego jako argumentu przemawiającego przeciwko podjęciu próby ustalenia racjonalizacji determinującej decyzje o karnoprocesowym sankcjonowaniu dowodów uzyskanych z naruszeniem praw jednostki. Biorąc pod uwagę daleko idące rozbieżności w tej materii, wymagałoby to na pewno pogłębionej pracy eksperckiej i żmudnego wykuwania kompromisu. Nie jest to jednak nic nadzwyczajnego we współczesnym, spluralizowanym świecie.

Ustalenie celu karnoprocesowego sankcjonowania dowodów uzyskanych z naruszeniem praw jednostki powinno determinować dalsze wybory dotyczące szczegółowych aspektów wprowadzanych regulacji prawnych. Doświadczenia wynikające $\mathrm{z}$ obcych porządków prawnych wskazują, że optymalnym rozwiązaniem jest przyjęcie jednego mechanizmu sankcyjnego, w ramach którego eliminowano by dowody uzyskane z naruszeniem praw jednostki. Ta reakcja wydaje się bowiem najbardziej optymalna. Kwestią wtórną, aczkolwiek ważną z perspektywy systemowej, jest ustalenie, czy powinno się to odbywać w ramach na przykład szerzej stosowanej instytucji nieważności czynności procesowej, czy też dostosowanej wyłącznie do realiów prawa dowodowego niewykorzystywalności wytworów czynności dowodowych. Należy jednak zastrzec, że z perspektywy celów procesu karnego, a przede wszystkim konieczności zapewnienia sprawiedliwości materialnej, wskazana sankcja powinna być stosowana $\mathrm{z}$ umiarem. Tam zatem, gdzie możliwe jest sięgnięcie po alternatywne środki o charakterze dyscyplinarnym, karnym czy cywilnym (na przykład w wypadku naruszenia prawa do prywatności przeszukiwanej osoby trzeciej, wadliwości proceduralnych w toku przeprowadzanych czynności, które nie wpływają jednak na ich ważność), powinno to nastąpić. Ustawowy system eliminacji wadliwych dowodów musi być elastyczny. Aby jednak uwzględnić kwalifikowany charakter niektórych uchybień w toku gromadzenia dowodów (wynikający na przykład z aktów prawa międzynarodowego), który automatycznie delegitymizuje proces karny, czyniąc go nierzetelnym, a także uniknąć nadmiernej swobody decyzyjnej organów procesowych, należałoby optować za systemem mieszanym, w którym przesądza się o niemożności wykorzystania niektórych dowodów uzyskanych z naruszeniem praw jednostki już na poziomie ustawowym. W pozostałym zakresie racjonalne byłoby natomiast zastosowanie mechanizmu ważenia racji przez sąd orzekający w sprawie. Regulacja taka powinna jednak określać, jakie kwestie sąd powinien zbadać oraz wskazywać na ogólną preferencję (inkluzywną albo ekskluzywną). Te dwa mechanizmy pozwalają bowiem przynajmniej do pewnego stopnia ograniczyć swobodę decyzyjną sądów, a zarazem przyczyniają się do lepszej weryfikowalności uzasadnień orzeczeń wydawanych w tej materii.

33 Ustalenie, jakie to powinno być uzasadnienie, wymagałoby osobnego opracowania. Własny pogląd na tę materię przedstawiłem w: ibidem, s. 87-147. 
Podsumowując, należy stwierdzić, że projektowanie racjonalnej regulacji karnoprocesowej dopuszczalności dowodów uzyskanych z naruszeniem praw jednostki powinno opierać się na szerokiej i wnikliwej analizie dorobku rodzimego oraz innych państw w tej materii. Przyjmowane regulacje muszą mieścić się w granicach wyznaczonych standardami konstytucyjnymi i prawnomiędzynarodowymi. Mając świadomość złożoności i kontrowersyjności decyzji podejmowanych w odniesieniu do karnoprocesowej dopuszczalności dowodów uzyskanych z naruszeniem praw jednostki, konieczne jest stworzenie mechanizmu, który z jednej strony będzie gwarantował niezbędną elastyczność uwzględniającą pluralizm racji mających znaczenie w procesie decyzyjnym, a z drugiej — tam, gdzie to możliwe, wyznaczał wyraźne granice oraz posługiwał się mechanizmami zapobiegający nadmiernej uznaniowości organów stosujących prawo. Wypracowanie takiego mechanizmu wymaga jednak w pierwszej kolejności określenia celu (celów), jakim miałby służyć. To zaś powinno odbyć się w ramach szerokich konsultacji z udziałem zarówno teoretyków, jak i praktyków prawa. Dotychczasowe doświadczenia związane z kształtem normatywnym i praktyką stosowania zakazu wykorzystania nielegalnie uzyskanego dowodu uregulowanego w art. 168a k.p.k. wyraźnie wskazują, że próby odgórnego dekretowania preferowanych przez ustawodawcę rozwiązań normatywnych są po prostu nieskuteczne, a na domiar złego generują niepotrzebne rozbieżności orzecznicze.

\section{REASONABLE REGULATION OF ADMISSIBILITY OF EVIDENCE OBTAINED IN VIOLATION OF HUMAN RIGHTS IN CRIMINAL PROCEEDINGS}

\section{Summary}

The article focuses on four requirements that must be met when drafting regulations on the admissibility of evidence obtained in violation of human rights. The first one assumes that a thorough analysis of both the theory and practice of functioning of national regulations regarding admissibility of improperly obtained evidence, as well as comparative analysis regarding that topic has to be conducted. Further, what requires consideration are constitutional and international standards forming a framework within which the legislator must fit. It is also necessary to clearly define the purpose of the regulations determining the admissibility of evidence obtained in violation of individual rights. The latter will allow consistency in drafting detailed regulations on who, how, and to what extent should admit the discussed pieces of evidence. The last issue is the choice of the optimum shape of a mechanism for sanctioning evidence obtained in violation of human rights. It should ensure a right balance in the distribution of power to decide on the admissibility of evidence between the legislator and law enforcement bodies, as well as the necessary flexibility with safeguards against excessive discretion.

Keywords: improperly obtained evidence, fair trial, human rights, law of evidence, admissibility of evidence 


\section{BIBLIOGRAFIA}

Bachmaier L., del Moral Garcia A., Criminal Law in Spain, Alphen aan den Rijn 2012.

Bodnar A., Wykonywanie orzeczeń Europejskiego Trybunału Praw Człowieka w Polsce. Wymiar instytucjonalny, Warszawa 2018.

Do Exclusionary Rules Ensure a Fair Trial? A Comparative Perspective on Evidentiary Rules, red. S. Gless, T. Richter, Cham 2019.

Exclusionary Rules in Comparative Law, red. S.C. Thaman, Dordrecht 2013.

Giannoulopoulos D., Improperly Obtained Evidence in Anglo-American and Continental Law, Oxford 2019.

Gruszecka D., [w:] System Prawa Karnego Procesowego, t. 8. Dowody, cz. 1, red. J. Skorupka, Warszawa 2019.

Hsiek K., The Exclusionary Rule of Evidence. Comparative Analysis and Proposals for Reform, London-New York 2016.

Jasiński W., Karnoprocesowa dopuszczalność dowodów uzyskanych $w$ wyniku tortur (standardy strasburskie), „Państwo i Prawo” 2011, nr 5.

Jasiński W., Nielegalnie uzyskane dowody w procesie karnym. W poszukiwaniu optymalnego rozwiazania, Warszawa 2019.

Kmiecik R., Dowód ścisty w procesie karnym, Lublin 1983.

Konstytucyjny spór o granice zmian organizacji i zasad działania Trybunału Konstytucyjnego: czerwiec 2015-marzec 2016, red. P. Tuleja, P. Radziewicz, Warszawa 2017.

Kremens K., Dostęp do obrońcy (adwokata) w orzecznictwie Sądu Najwyższego USA (Doktryna Mirandy), „Europejski Przegląd Sądowy” 2018, nr 1.

Kwiatkowski Z., Zakazy dowodowe w procesie karnym, Kraków 2005.

Roberts P., Excluding evidence as protecting constitutional or human rights?, [w:] Principles and Values in Criminal Law and Criminal Justice. Essays in Honour of Andrew Ashworth, red. L. Zedner, J.V. Roberts, Oxford-New York 2012.

Sobolewski Z., Illegal evidence and the Polish criminal procedure, „Annales Universitatis Mariae Curie-Skłodowska" 1988, nr 1.

Sobolewski Z., Samooskarżenie w świetle prawa karnego (nemo se ipsum accusare tenetur), Warszawa 1982.

Sobolewski Z., Wartość nielegalnie uzyskanego dowodu w postępowaniu karnym, „Annales Universitatis Mariae Curie-Skłodowska” 1976, nr 1.

Szumiło-Kulczycka D., Wykorzystanie w procesie karnym dowodów pochodzacych z czynności pozaprocesowych policji i innych dziatajacych stużb - raporty krajowe, [w:] Pozaprocesowe pozyskiwanie dowodów i ich wykorzystanie w procesie karnym, red. P. Hofmański, D. Szumiło-Kulczycka, P. Czarnecki, Warszawa 2015.

Thaman S.C., ,Fruits of the poisonous tree” in comparative law, „Southwestern Journal of International Law" 2010, nr 16.

Turner J.I., Weigend T., The purposes and functions of exclusionary rules: A comparative overview, [w:] Do Exclusionary Rules Ensure a Fair Trial. A Comparative Perspective on Evidentiary Rules, red. S. Gless, T. Richter, Cham 2019.

Wąsek-Wiaderek M., Model zakazów dowodowych z perspektywy Konwencji oraz orzecznictwa ETPCz, [w:] Nowe spojrzenie na model zakazów dowodowych w procesie karnym, red. J. Skorupka, A. Drozd, Warszawa 2016.

Weigend T., The potential to secure a fair trial through evidence exclusion: A German perspective, [w:] Do Exclusionary Rules Ensure a Fair Trial. A Comparative Perspective on Evidentiary Rules, red. S. Gless, T. Richter, Cham 2019. 